\title{
JOHANNA WAGNER AND THE RIVAL
}

OPERA HOUSES

By

S.M. Waddams

Reprinted from

\section{LAW QUARTERLY REVIEW}

July 2001

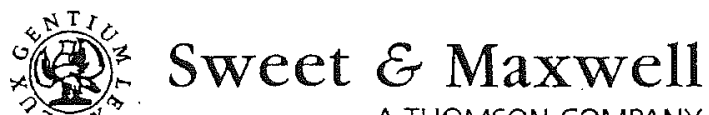

A THOMSON COMPANY

Sweet \& Maxwell Limited 100 AVENUEROAD

SWISS COTTAGE

LONDON

NW3 3PF

(Law publishers) 


\section{JOHANNA WAGNER AND THE RIVAL OPERA HOUSES}

"A MANAGER of a London opera house" wrote Hector Berlioz, observing the London musical scene in 1851, "is a man who carries about a barrel of gunpowder and cannot put it down becaüse he is pursued with flaming torches. The poor devil runs as fast as his legs will carry him, falls down, gets up again, leaps over ditches, palings, streams, and bogs, knocks down everything he meets, and would trample on the bodies of his father or his children if they got in his way". "This comment could not be better illustrated than by the competition between the two principal opera houses in 1852 for the services of Johanna Wagner, a competition that produced two leading cases, Lumley v. Wagner ${ }^{2}$ (1852) and Lumley v. Gye ${ }^{3}$ (1853), decisions determining crucial issues of fundamental importance in English private law. The then very recent Common Law Procedure Act of $1852,{ }^{4}$ putting an end to the forms of action, had opened the question of organisation and classification of concepts. ${ }^{5}$ Contract, wrongdoing, unjust enrichment, property, and public policy were all involved in these cases, and interrelated in a complex way. Failure to recognise the complexity of this interrelationship has led, I will suggest, to a misunderstanding of the decisions themselves, and consequently to a misapplication of them in subsequent cases.

Besides this complexity there is another, also well illustrated by these cases, namely the interrelation of facts with law. The "facts" of a case are defined in relation to legal principles, but the legal principles themselves are necessarily formulated in relation to facts, real or hypothetical. On two issues in this dispute facts were initially presented in response to perceived legal principles, but when the facts could not be sustained, the legal principles were reformulated and the facts newly presented to fit them. On a third issue-whether Gye honestly believed that Johanna Wagner was entitled to terminate her contract with Lumley-the same would probably have happened again had it not been for a sharp separation between law and facts required by the procedure adopted under another provision of the 1852 Act. This aspect of Lumley v. Gye has been widely misunderstood, leading most modern commentators to the erroneous conclusion that Lumley won the case; in fact the eventual result was a victory for Gye.

\footnotetext{
${ }^{1}$ H. Berlioz, Evenings with the Orchestra (1852) tr. J Barzun (1956), p. 113.

${ }_{2}^{2}$ (1852) 5 De G. \& Sm. 485, 19 L.T. 127, I De G.M. \& G. 604, 21 L.J. Ch. 898, 16 Jur. 871, 19 L.T. 264.

${ }^{3}(1853) 2$ El. \& B1. 216, 22 L.J. Ex. 9,22 L.J.Q.B. 463,16 Jur. 1048, 1 W.R. 39, 432, 20 L.T. 71,81 , 103 and (1854) $3 \mathrm{El}$. and Bl. 114, 17 Jur. 827, 18 Jur. 466, 468 22 L T 134, 220, 23 LT 66, 157,23 4. Q.B. 112,116 .

${ }^{s} \mathrm{G}$. Samuel and J. Rinkes, Law of Obligations and Legal Remedies, (1996), pp. 11, 78, 80.
} 
Gye's diaries, recently accessible, ${ }^{6}$ throw new light on his perspective throughout the dispute.

The background of these cases - was a fierce rivalry between $\mathrm{Her}$ Majesty's Theatre, Haymarket, managed by Benjamin Lumley, ${ }^{7}$ and the then fairly new Royal Italian Opera, Covent Garden, managed by Frederick Gye ${ }^{8}$ Her Majesty's had been "practically the sole home of Italian opera" until "the opening of the rival opera-house in 1847", and in the succeeding years each opera house attempted to take over the other's business. ${ }^{10}$ Personal relations between the two managers were not cordial. Gye wrote in his diary in December 1851, with reference to a failed negotiation" for Covent Garden to lease Her Majesty's Theatre:

"Saw Lumley again but he wd not sign the agreement altho' he said at first it was a correct embodiment of our meaning-he shuffled and told all sorts of lies-I have heard bad things of Lumley \& now find him a devil incarnate-the most dreadful rascal with the smoothest face \& manner I ever in the whole course of my life met-he promised to write me in a few days. He again pressed me to give up the two theatres to him and offered $£ 5,000$ down and $£ 5,000$ a year income, with a banker's security." 12

Two months later Gye recorded that Lumley had threatened that "there would be war to the knife \& he would crush me and Covent Garden too!!!". 13 At the trial, his counsel said that Gye felt that he owed. "no delicacy to Mr. Lumley", ${ }^{14}$ by which he meant, no obligation to do Lumley any favours.

The rivalry between the two opera houses had been the cause of earlier litigation. There had been a dispute (with the interests of the parties effectively reversed $)^{15}$ in 1847 , involving Jenny Lind, one of the most famous operatic singers of the century, who, having signed first with another theatre (Drury Lane, then specialising in operas sung in English), ${ }^{16}$ broke her contract, sang at Her Majesty's, and was held liable for damages

- Deposited at the Royal Opera House in 1994.

7 1811-1875, Dictionary of National Biography; F. Boase, Modern English Biography (1892-1921); The Jewish Encyclopaedia (1901); Encyclapaedia Judaica (1929); Universal Jewish Ercyclopedia (1942); B. Lumley, Reminiscences of the Opera (1864); P. H. Enden, Jews of Britrin, (1943), pp. 510-512. ${ }_{8} 1810-1878$, Dictionary of National Biography; G. Diderickson and M. Ringel, "Frederick Gye and the 'Dreadful Business of Oppra Managenen'",

ley. See Wyndham, Annals of Covent Garden

to G. Dideriksen, "Repertory and Riviry

To G. Dideriksen, "Repertory and Rivalry: Opera at the Second Covent Garden Theatre, 1830-1856", Ph.
D. thesis, London, 1997, 82, The Times, February 21, 1854, p. 9d.

"Referred to at the trial, The Times, February 21, 1854, 9d, February 22, 1854, p. Ilb.

12 Gye's diary, entry for December 25, 1851, Royal Opera House Archives, quoted in part in Didericksen and Ringel, "Frederick Gye and the "Dreadful Business of Opera Management" (supra, n. 8), p. 7.

${ }^{13}$ Gye's diary, February 18, 1852 (letter of Lumley to third person).

i4 The Times, February 22, 1854, p. 11 .

Alfred Bunn, who had originally engaged Lind, assigned his interest in the contract to Covent Garden

Nalbach, The King's Theatre, 1704-1867: London's First Italian Opera House (1972), p. 106.

th $\mathrm{E}$. W. White, A History of English Opera (1983), pp. 298-299.

(2001) 117 L.Q.R., JULY (C) SWEet \& MAXWELL AND CONTRIBUTORS for breach of contract. Alfred Bunn, the manager of the Drury Lane theatre, brought an action for damages against Lind which led to a jury award of $£ 2,500,{ }^{17}$ ultimately settled for $£ 2,000 .{ }^{18}$ Lumley, who was alleged to have taken advantage of Lind's breach of contract in order to meet the competition from the new opera house at Covent Garden, ${ }^{19}$ made a very handsome profit out of the transaction, even after indemnifying Lind and paying her fee. ${ }^{20}$ This case, suggesting both that the ordinary remedy of damages for breach of contract was ineffective in these circumstances and that the real dispute was between the rival employers, must almost certainly have been in the minds of the judges when they came to deal with Lumley's cases against Wagner and Gye four years later. ${ }^{21}$ It is significant that the Lind case appeared to raise no legal point of interest, and was not reported in any law reports, whereas the Wagner dispute, on very similar facts, produced two leading cases.

Success in the London opera business at the time depended principally on attracting new star performers. ${ }^{22}$ Johanna Wagner ${ }^{23}$ was, like Jenny Lind, a star. Lumley, who had profited so handsomely from Lind's London appearance, confidently anticipated equal success with Wagner, and witnesses at the trial said that "the Wagner fever" was "quite as violent" as "the Lind fever". ${ }^{24}$ The history of the negotiations was complex, and shows the extraordinary efforts of the two rival managers to secure Johanna Wagner's services. She was first in contact with Gye, who had heard her sing as early as 1845 . He wrote in his diary, in January 1850 :

"Mdlle Wagner is a tall, handsome woman about 24, fair, with beautiful eyes hair and teeth \& very graceful-her voice is of great compass, is clear powerful and good in all parts; she sings perfectly in

${ }^{17}$ The Times, February 23, 1848, p. $8 \mathrm{~b}$.
${ }^{18}$ The Times, January 23, 1849, p. $7 \mathrm{~d}$.

19 Bunn v. Lind, The Times, February 23,1848 , p. $7 \mathrm{f}$, counsel's argument ("It was necessary to the very existence of Mr. Lumley that he should get her").

${ }^{20}$ An indemnity was alleged by plaintiff's coursel, denied by defendant's solicitor at the trial, The Times, February 23, 1848, p. 7f, and admitted by Lumley, Reminiscences of the Opera (1864), p. 163. Nalbach, The King's Theatre, 1704-1867 (1972), p. 106, states that an indernnity was promised. See also Wyndham, Annals of Covent Garden (1906), 185. Lumley paid Lind $\pm 5,600$ for the season of 1847 (Nalbach, p. 106), The amount of damages awarded against Lind was $£ 2,500$ (later settled for $£ 2,000$ ), but the rakings of the theatre in 1847 for 39 rights of her performances were stated to be the enormous sum of $\{45,924$, 6s: The 21 Tebruary 22, 1854, p. 101, Morning Post, February 22, 1854, p. 6e (£45,944).

"The cases were linked in The Times, May 3, 1852, p. 5 f "Scandals like the Lind and Wagner squabbles this country with two engagements, Ap".) by C. L. Gruneisen, The Opera and the Press (1869) p. 10 and by H. F. Chorley, Thircy Years' Musical Recollections, (1862), p. 312. Erle J., who presided at the trial in Burn v Lind, was one of the majority judges who decided the demurrer in Lurmley v. Gye.

${ }^{22}$ The Times, February 2l, 1854, p. 9d.

${ }^{23}$ 1826-1894, niece (by adoption) of Richard Wagner. J. Kapp and H. Jachmann, Richard Wagner und seine erste Elizabeth, (1927), trs. Maria Anna Trechman, (1944); New Grove Dictionary of Opera, (1992) s.n. Johanna Wagner, New Grove Dictionary of Music and Musicians, (1980), s.n. Wagner, Deutches Theater-Lexikon, ed. Wilhelm Kosch, (1960), s.n. Jachmann-Wagner, Grosses Saengerlexikon, ed. K.J. Kutsch and Leo Riemens, (1997), s.n. Wagner-Jachmann, Ox-Wad Dur E. West, $(1992)$, sit. Jo,

(2001) 117 L.Q.R., July @ C SWeEt \& MAXWELl ANd CONTRIBUtoRS 
tune and acts well but wants a little good Italian tuition--she would hold an excellent position in London or Paris \& bids fair to be one of the first singers in Europe." 25

Gye made Johanna Wagner an offer in 1850 , and again in $1851,{ }^{26}$ but she was engaged elsewhere. Gye went to see her in Berlin in September 1851 to discuss the 1852 season, and left with the expectation that, if she came to London, she would sing at Covent Garden. But then she was approached by Dr. Joseph Bacher, an intermediary acting in Lumley's interest, who persuaded her to make an agreement with Lumley and Her Majesty's Theatre for 1852. Gye's counsel later accused Bacher of having induced this transaction by "the most cunning misrepresentations", but these amounted, it seems, to little more than comparisons between the two opera houses (to the disadvantage of Covent Garden) and suggestions that the English press was favourably disposed towards Lumley. ${ }^{27}$ Comparisons of this sort were common on both sides of such negotiations, and misrepresentation was not seriously argued as a legal defence.

Lumley's first offer was of $£ 800$ for a three-month engagement. There is little evidence to support the view (though it is occasionally put forward by commentators ${ }^{28}$ ) that Lumley took any kind of improper advantage of Johanna Wagner. In response to the suggestion of abuse of confidence, the Lord Chancellor said, "Now I never saw a case in which there was less foundation for that charge". ${ }^{29}$ Johanna Wagner was advised throughout by her father, and they knew their bargaining position was strong, as Gye had proposed to Wagner in the previous September a fee of $£ 300$ per month. ${ }^{30}$ So strong indeed was their bargaining position that they rejected Lumley's printed form, and drafted their own contract (in French), omitting most of the terms onerous to Wagner, and increasing the fee by 50 per cent, to $£ 1,200$. This counter-offer omitted the stipulation that she would not sing elsewhere without Lumley's permission during the term of her engagement, a term that was, of course, crucial to Lumley, in view of the rivalry with Covent Garden. Lumley accepted the increased fee and all Wagner's other terms, but insisted on reinserting the exclusivity clause, to which Bacher purported to agree on Wagner's behalf. Lumley signed the document, and Bacher sent it to Johanna Wagner, who acknowledged receipt on November 27,1851, saying "all is in the best order". ${ }^{11}$ The ${ }_{25}$ Gye's travel diary, January 5, 1850, quoted in Didericksen and Ringel, "Frederick Gye and the
'Dreadful Business of Opera Management'" (supra, n. 8), p. 26.

26 Morning Post, April 22, 1852, p. Se (letter from Albert Wagner), The Times, February 22, 1854, p 11 a.

${ }^{27}$ The Times, February 22, 1854, pp. $10 \mathrm{f}$ and 11 a

${ }^{28}$ See, for example, L.S. VanderVelde, "The Gendered Origins of the Lumley Doctrine: Binding Men's Consciences and Wormen's Fidelity" (1992) 101 Yale L.J. 775.

${ }^{29}$ 19 L.T. 267

${ }^{30}$ Gye's travel diary, September 25-27, 1851. Dideriksen describes this as "a relatively high monthly and Rivalry", 273.

(2001) 117 L.Q.R., July ( SWEet \& MAXWELl AND Contributors added clause was as follows (retranslated, not very idiomatically, from French):

"Madlle. Wagner engages herself not to use her talents at any other theatre, nor in any concert or reunion, public or private, without the written authorization of Mr. Lumley." 32

Joseph Bacher, the intermediary in these negotiations, was previously known both to Lumley and to the Wagners, and there was some uncertainty about whose agent he really was. He was a doctor of civil law of Vienna, but not a practising advocate. He had worked for nine years in an advocate's office, and since then, according to his evidence at the trial, "I have occupied myself with art". ${ }^{33}$ He was introduced to Johanna Wagner in 1850 through the composer Giacomo Meyerbeer, heard her sing privately, and "soon after" recommended to Lumley that he should engage her. Bacher acted for Lumley in other transactions, ${ }^{34}$ and his brother-in-law had lent Lumley a large sum of money. ${ }^{35}$

There was room, therefore, for uncertainty about Bacher's role. His affidavit in the Chancery court stated that he was authorised to agree to the crucial clause as Wagner's agent, but Albert and Johanna Wagner strenuously denied this in two separate affidavits. ${ }^{36}$ Bacher said that the clause had been previously discussed with the Wagners and omitted from their counter-offer "by mistake", ${ }^{37}$ but in their affidavit Albert and Johanna Wagner said that they had specifically objected to the prohibition against singing at private concerts, and that the clause was omitted "purposely". 38 Here the weaknesses of affidavit evidence, untested by cross-examination, become apparent. What kind of "mistake" was Bacher alleging? The word could cover a variety of states of mind. The affidavits on both sides agree in stating that the matter was expressly discussed, and so it is highly

32 I9 L.T. 127. The French version was itself a rough translation of Lumley's original printed English ${ }^{32} 19$ L.T. 127 . The French version was itself a rough translation of Lumley's original printed English
version: 5 De G. \& Sm. 496 . The Wagners communicated in French with Lumley and Gye, and in German version: 5 De G. \& Sm. 496 . The Wagners communicated in French with Lumiey and Gye, and in German
with Bacher.
33 The Times. February 21 1854. Lord Campbell was sceptical about this. In summing un he said "I

must confess that there was a lirtle suspicion in my mind from a doctor of laws of Vienna saying that he was merely induced to enter into theatrical inansactions for love of art. Now if he is not the paid agent of was merely induced to enter into theatrical transactions for love of art Now if he is no
Mr. Lumley, he is at all events the agent": Moming Post, February 23, 1854, p. $7 \mathrm{~b}$.

${ }^{34}$ Affidavit of Carl Formes, P.R.O. C31/861.

3s Bacher's brother-in-law, Louis Brandus, a prominent music-publisher in Paris, had lent Lumley £8,000, probably in support of the operations of the Italian Opera House in Paris, of which Lumley was also the manager from 1850 to 1851. See The Times, February 21, 1854, p. 9f (name spelled "Brandhurst") Morning Chronicle, February 21, 1854, p. Ilf ("Brandis"); Morning Post February 21, 1854, p. 7 ("Brundirs"); affidavit of Frederick Chappell, P.R.O. C31/861; Dictionnaire des Editeurs de Musique Francats, ed. A. Devries et F. Lesure (1988) ii, 72-9; A. Devries, "La Maison Brandus: Heurs et Maaheurs Brandus brought legal proceedings in England to enforce the debt: 19 L.T. 125, The Times May 7, 1852 p. $7 \mathrm{~b}$.

36.R.O. C31/861

37 "And I say that this point had been well considered and spoken of.by the said defendants Johanna Wagner and Albert Wagner with me at Berlin .... and accepted by them and the same having by mistake been left out in the agreement so signed ,...": P.R.O. C31/86

P.R.O. C31/861.

(2001) 117 L.Q.R., JuLY @ SweEt \& MAXwell AND Contributors 
improbable that Albert Wagner, who wrote the agreement in his own hand, actually intended to include the clause in Lumley's exact words, but accidentally forgot to do so, and the omission was overlooked by Bacher. The Wagners probably objected, as they said in their affidavit, to the breadth of the clause on the ground that it unreasonably and unnecessarily extended to private concerts, an objection that Albert Wagner repeated in a letter to Bacher of February $21,1852 .{ }^{39}$ Had they considered the question they perhaps would have recognised that it was a reasonable stipulation that she should not sing at other theatres during the term of her engagement with Lumley, but there is a difference between such a recognition and an actual intention to agree to a specific clause, and such a state of mind is not very accurately described as an omission of Lumley's clause "by mistake".

When it came to the courts, this point was eventually resolved in Lumley's favour, but not on the ground that Bacher had the authority he claimed to have had. The judges who considered the facts of the case all concluded that Bacher had no such authority, and that when Bacher sent the amended document back to the Wagners, this amounted merely to a further counter-offer. The Wagners would have been free at that point to break off negotiations, but, instead of doing so, they impliedly acquiesced in the disputed clause. Johanna Wagner had in effect accepted the clause by saying that all was "in the best order", and Albert Wagner had grumbled about the exclusivity clause, but had not rejected it. ${ }^{40}$ As Lord St Leonards put the point, "M. Wagner finds fault [with the wide terms of the clause]; but in that very act of finding fault he acquiesces; he does not like it; but the very finding fault with it without saying ' $I$ will not be bound by it' is a clear acquiescence". ${ }^{41}$ Thus, the document signed by Lumley, which all the witnesses and the legal documents had called "the contract" was not, legally speaking, a contract at all, but a mere counter-offer. Bacher's insistence that he had actual prior authority to agree to the clause on Johanna Wagner's behalf turned out to be unnecessary, and indeed counterproductive from Lumley's point of view, because it cast doubt on the reliability of other aspects of Bacher's affidavit.

Johanna Wagner was conscious that in making the agreement with Lumley she had disappointed Gye's expectations. She wrote apologetically to him to say:

"I must naturally appear ungrateful to you; but we have told you again and again the peculiar reasons which compel me for this once to sing and Mr. Lumley's against my feelings; you know them well. I expect little good from this engagement; but, on my word, I could not act

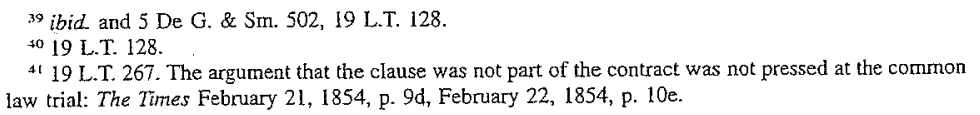

19 1267 . The argument that the clause was not part of the contract was not pressed at the common law trial: The Times February 21, 1854, p. 9d, February 22, 1854, p. 10e.

(2001) 117 L.Q.R., JULY @ SWEET \& MAXWELL AND CONTRIBUTORS otherwise. I am very unhappy about it-I and especially my father who expects nothing but evil from this connexion. Nevertheless, I hope for your pardon and even that you will receive us in London as friends. Will you not, Monsieur?" 42

Gye went to see Johanna Wagner in Berlin in January 1852, and suggested that she should sing at Covent Garden in the 1853 season. He added:

"I told her that if Lumley played any tricks with her so that she could honorably get out of her engagement with him this year I wd give her such an engagement for $1853 \& 4$ as wd repay her for the money she might lose this year - this is by not fulfilling L's engagement." 43

Two days later Gye saw her again and suggested that she might sing at Covent Garden in 1852 after her engagement with Lumley was over:

"She seemed to like this idea. She then said in a confidential way-depend upon it I will break L's engagement if I have an opportunity." 44

This shows that Gye, while ever anxious to advance his own interests at Lumley's expense, did not at this time anticipate that Wagner would sing elsewhere than at Her Majesty's Theatre between April and June 1852. But the conversation may be said to amount to an understanding between them that Wagner's long-term interests in London were likely to lie in the direction of Covent Garden rather than the Haymarket.

Lumley, naturally, set about to make the most of his prize, selling the rights to booksellers who were, at this period, retailers of theatre tickets. ${ }^{45}$ Very large sums of money were involved:

"So powerful was the prestige of Mademoiselle Wagner's name at that period, and so confident the anticipations of her great success, that subscriptions among the operatic booksellers, the 'middlemen' of operatic lettings, were unprecedentedly large this season. Mr. Mitchell alone subscribed for $£ 10,000 .{ }^{46}$ It is not the place here to dilate upon the workings for good or evil of this system, which has taken so firm a root in the theatrical affairs of London." 47

${ }^{42}$ Letter received December 7,1851 , The Times, February 22, 1854, p. 11a. The admissibility of this ${ }^{42}$ Letter received Decernber 7,1851 , The Times, February 22,1854, p. 11a. The admissibility of this
letter and of Gye's reply to it was challenged, but upheld by the Queen's Bench: The Times, April 22, 1854, letter and of Gye's reply to it was challenged, but uphed
p. $11 \mathrm{~b}$, June 2,1854, p. 9 e, and June 6,1854, p. 9 a.

${ }_{43}^{4}$ Gye's diary, January $22,1852$.

4." Dideriksen and Ringel, "Frederick Gye and the 'Dreadful Business of Opera Management'" (supra, n. 8), p. 6.

${ }^{46}$ John Mitchell gave evidence in Bunn p. Lind, The Times, February 23, 1849, p. 7f, made an affidavit in the Chancery suit, P.R.O. C31/861, and gave evidence at the trial in Lumiey v. Gye, The Times, February 21,1854 , p. 9f. There he said that he had undertaken to pay Lumley $£ 15,400$ to rent boxes and stalls, and eventually settled his obligations for $£ 10,000$. Gye recorded in his diary that Mitchell told him he had scribed for $\{15,000$; April 13,18

Lom

(2001) 117 L.Q.R., JULY (C) SWeEt \& MAXWELl AND CoNtributors 
By the terms of the agreement, Wagner was to commence her engagement on April 1, 1852, and Lumley was to make an advance payment of $£ 300$ on March 15. On February 6, Wagner requested a postponement of the starting date to April 15, and Lumley assented, no mention being made by either party of changing the date for payment of the advance. ${ }^{48} \mathrm{By}$ February, Johanna Wagner and her father were regretting their bargain, having formed the view that they could have obtained a much better price for Johanna's services. ${ }^{49}$ Moreover, they were changing their opinion of the comparative merits of the two theatres. Lumley's financial position was now unstable, and on March 13 he was arrested for debt. ${ }^{50}$ March 15 came and went without payment of the $£ 300$. Gye now wrote twice to Wagner (March 9 and 30), ostensibly to enquire whether her engagement with Lumley was firm, and, deducing from the absence of a reply that there might be doubt about this; he decided to go to Germany. By coincidence, Lumley was on the same train to Dover, and Gye made a sudden and drastic alteration in his travel plans in order to avoid him:

"I went home to dinner \& at half past 8 left by mail train to Dover ..

I had made up my mind to go to have a last trial to engage Mdlle. Wagner. After taking my seat on the train I saw Lumley on the platform. Of course I did not wish him to see me as he might suspect something so at Dover I rushed out of the train \& down to the Ostend boat leaving [a travelling companion] to see to the baggage. I presume L went to Paris as I saw no more of him." 51

Gye missed the Wagners in Berlin but found them at Hamburg, where he made her a very attractive offer: $£ 2,000$ for a two-month engagement, with $£ 1,000$ payable in advance. Wagner told him that Lumley was in default of payment of the sum due on March 15 and that she therefore considered herself free, and she accepted Gye's terms, repudiating her contract with Lumley.

Gye's state of mind at this point later proved to be the crucial question at the common law trial. His diary which, probably fortunately for Gye, was not available to Lumley's counsel at the trial, reveals that Wagner's inclination had been to honour her commitments to Lumley, at least to the extent of giving him further time to pay the advance, and that Gye had exerted strong persuasive pressure upon her:

"I soon found that there was a screw loose \& she [Johanna Wagner] told me that Lumley's engagement compelled him to pay her $£ 300$ on

${ }^{48}$ The Times, April 24, 1852, p. 8b, and February 21, 1854, p. 9d.

${ }^{48}$ The Times, April 24, 1852, p. 8b, and February 21,1854 , p. 9 d.
${ }^{49}$ Letter of A. Wagner to J. Bacher, February 21,1852 , in Lumley's first affidayit, reproduced in 19 L.T 128.

${ }^{50}$ Lumley stated in his affidavit that this was on account of his having made himself liable as guaranto of another's debt. He spent three days in custody and the debt was paid in full: affidavit of May 5, P.R.O. C31/861.

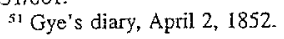

(2001) 117 L.Q.R., JuLY @ SWEET \& MAXWELl AND CONTRIBUtorS
March 15 but that she had not yet received it. She said every one had wamed her against $L$ but that Dr. Bacher had very much deceived her Her father said of course $L$ had broken his engagement-I told them that no one was paid of Lumley's artistes in Paris-that no preparation was made for The Prophet-also that he had been arrested in London $\&$ that taking all these things together, it would be madness to give $\mathrm{L}$ any more time when she now had an opportunity of escaping from an engagement, which surrounded as she would be by $2 \mathrm{~d} \& 3 \mathrm{~d}$ rate artistes could but do her injury - her engagement with $\mathrm{L}$ was for 3 months for $£ 1200$ - I offered her $£ 2000$ for 2 months \& to take all risks of law suit on my shoulders - To this they agreed and after much hesitation \& fear she signed her engagement. I gave her a cheque on Coutts for $£ 1,000$ also a letter about the law suit taking on myself the responsibility." 52

It will be seen from this entry that Gye expected a lawsuit, and consciously calculated that he could afford to take the risk of having to pay common law damages and costs, just as Lumley had done in respect of Jenny Lind It is clear that Gye did not anticipate an injunction, or a direct action against himself, nor, had he sought legal advice, is it probable that, as the law then stood, his advisers would have been able to predict them.

Gye returned to England but then went back to Germany to meet Wagner and to accompany her personally to London. His precautions were justified, for Lumley had not given up. On April 13 he and Mitchell, the bookseller who had a $£ 15,000$ interest in Johanna Wagner's appearing at Her Majesty's, went to Hamburg with the full contract amount of $£ 1,200,{ }^{53}$ in a final attempt to persuade Wagner to change her mind. She refused, but Lumley and Mitchell travelled on the same train with her from Hamburg to Cologne, where Gye met her and "took charge of her to London". ${ }^{54}$ The scene at the Cologne railway station must have been dramatic. Gye wrote in his diary: "At 10, I met Mlle. Wagner, with her father and friend Mme. Cohn, she taking my arm and we walking her off before Lumley and Mitchell who were also in the train." 55

${ }^{52}$ Gye's diary, April 5, 1852, quoted in part in Didericksen and Ringel, "Frederick Gye and the "Dreadful Business of Opera Management" ${ }^{\text {" }}$ (supra, n. 8), p. 24. The cheque was paid: Dideriksen "Repertory and Rivalry", 224 note, referring to Coutts' ledger. The opera mentioned is "Le Prophete" by Giacomo Meyerbeer, in which Wagner was to sing the part of Fides, one of her favourite parts and the part in which she was to open at Covent Garden on April 24; see letter of Albert Wagner to Bacher, February Chancery bill shows that the puzzling expression in L T "Tab is better than Fid" is based on a misreadin "I "Jh[antal prefers Fid[e]".

${ }^{3} \mathrm{Gye} ' s$ counsel made much of this in argument at the trial, as showing that the advance payment of
$\$ 300$ had not been previously made or tendered: The Times, February 22, 1854, p. 11b. But the argument is not conclusive, as Lord Campbell pointed out to the jury (Morning Chronicle, February 23, 1854, 7b) because, even if the $£ 300$ had been previousiy offered by Bacher, there would be nothing inconsistent in offering it again.

The Times, February 21, 1854, p. If (evidence of John Mitchell).

${ }_{55}^{5}$ Gye's diary, April 17, 1852, quoted in Dideriksen and Ringel, "Frederick Gye and the 'Dreadful Business of Opera Management" (supra, n. 8 ), p. 25.

(2001) 117 L.Q.R., July @ Sweet \& MaXwell and Contributors 
Johanna Wagner arrived in London with Gye, and her debut was announced for April 24 at Covent Garden. ${ }^{56}$ But Gye's victory was shortlived. On April 23 Lumley obtained an ex parte injunction from a ViceChancellor (Sir James Parker) to restrain her from appearing. The injunction was continued by the Vice-Chancellor on May 10, and an appeal was dismissed by the Lord Chancellor (Lord St Leonards) on May 26. Just as Gye's victory was short-lived, so also was Lumley's, for in the end Wagner did not sing at either theatre, and the 1852 season was a disaster for Lumley, and for Her Majesty's theatre, which closed from 1853 to 1855 , Lumley attributing the closure largely to Johanna Wagner's defection. ${ }^{37}$ As we shall see, Lumley eventually lost his legal action against Gye for damages, so in the end Lumley, Gye, Wagner, and the opera-going public-everyone in fact except the lawyers-were all losers.

Proof of facts in the Chancery Court was by written affidavit, and 39 were filed ${ }^{58}$ Parker V.-C. found; as we have seen, that Wagner had, by her subsequent conduct, impliedly agreed to the exclusivity clause. On the question of the non-payment by Lumley of the $£ 300$ he said, revealing a surprising ignorance of the common law, and of the obvious purpose of an advance payment, ${ }^{59}$ that non-payment would not, as a matter of law, entitle Wagner to terminate the contract, i.e. that it was not a condition precedent. In the higher Chancery court this last question was determined in Wagner's favour, Lord St Leonards saying that "I am clearly of opinion that Mr. Lumley could not come here to enforce that contract unless he had put himself right by tendering at a proper and reasonable time the $£ 300$ which he had stipulated to pay", adding "Observe what a hardship it would be" ${ }^{60}$ This interpretation was later confirmed by the common law court at the trial. ${ }^{61}$ But Lord St Leonards found that Lumley had paid the money to Bacher for transmission to Wagner in good time, and that she had been informed of the fact. He thought that Wagner had deliberately evaded receipt of the money in order to escape from the contract: "I think it is entirely her own fault, and that she intended, as far as she could, to prevent the money being paid in order to escape the liability of performing the contract." 62

As we saw in respect of the exclusivity clause, affidavit evidence has certain weaknesses, and the facts on this issue appeared rather differently

${ }_{57}^{56}$ The Times, April 21, 1852, p. 8d

opera, p. 335, D.N.B., s.n. Benjamin Lumley.

C3N/861.

${ }^{59}$ To cover travel expenses and to give security for Lumley's counter-performance. Parker V.-C. also made the point that the time for payment had been impledly extended: 5 De G. \& Sm. 511-512. See text at חn. $72-73$, infra.

${ }_{60}^{60} 19$ L.T. 267.

${ }^{61}$ The Times, February 23, 1854, p. 12c ("condition precedent"),

${ }^{62} 19$ L.T. 267.

(2001) 117 L.Q.R., JUly $\odot$ SWEET \& MAXwell and Contributors when oral evidence was heard nearly two years later at the jury trial. ${ }^{63}$ As the facts then appeared, Johanna Wagner was far from eager to break her contract with Lumley. She gave Gye no encouragement; she did not reply to either of his March letters, and when he did appear in Hamburg uninvited, she urged him to allow a few more days to see whether Lumley would meet his obligation. Despite her inclination to favour Gye, ${ }^{64}$ she was very conscious of her obligations to Lumley, and expected, until April 5, to fulfil them. She signed the agreement, as Gye's diary now confirms, only after much hesitation. Lord St Leonards, seeking to derive the facts from the affidavits, relied very heavily on Bacher's statement that he had written to Albert Wagner on March 10 offering to pay the $£ 300$, and the implication that she had not replied to the letter:

"Dr. Bacher writes to M. Wagner to say that he, Dr. Bacher, had the $£ 300$ to pay to Mdlle. Wagner, and asking her how and where he should send it. He swears to the contents of that letter, and he swears that he received no answer to it. ${ }^{65}$ Now what is the allegation on the other side? That they remember they did receive a letter of the 10 th of March; but they contradict in the flattest terms, the truth of Dr Bacher's statement in regard to the contents of that letter. I called for the production of that letter, and I am not satisfied with the account given of its non-production. Dr. Bacher does not know that that letter is not in existence, and he swears, in the first instance, to the absolute contents of that letter as a positive fact, not knowing, as he could not know if he were swearing falsely, that the letter might not be produced the next hour in order to establish the falsehood of which he was guilty. If, therefore, a party at that peril makes such an affidavit in the first instance, and the other party merely says that it is not true that those are the contents, I must take the contents to have been as Dr. Bacher has swom they were." 66

But in his oral evidence at the trial, Bacher said that he had received an answer to the letter of March 10: "I know she received my letter because she wrote to me an answer." So, where was this letter of Wagner's? Bacher said, "I have not got the letter now. I parted with it during the proceedings in Chancery. I gave it to Mr. Lumley or to Mr. Jennings [Lumley's solicitor]". This revelation seems to have come as a surprise to counsel, as the newspaper report states that "after considerable discussion, it was stated that such letter was not in the plaintiff s possession" ${ }^{67}$ Bacher was thus vulnerable to the accusation of having made a misleading affidavit to the Court of Chancery on a crucial point, and, not surprisingly, Gye's

${ }^{63}$ The Times, February 22, 1854, p. $11 \mathrm{~b}$ (Attorney-General's address to jury for Gye); February 23, p. 12c (judge's direction to jury)

${ }^{64}$ See diary entries for January 22 and 24, 1852, discussed supra.

${ }^{65}$ Bacher's affidavit was silent on this point.

${ }^{67}$ The Times, February 21,1854 , p. $9 e$.

(2001) 117 L.Q.R., JULY $\odot$ SWEET \& MAXWELL AND CONTRIBUtorS 
counsel made the most of this in his address to the jury at the common law trial. Moreover, neither Lumley nor Jennings were called as witnesses, casting doubt on Bacher's claim to have given the letter to them. Of course, as Gye's counsel implied, it was highly improbable that either Lumley or his solicitor, having been given such a letter after commencement of legal proceedings, would have lost it:

"Dr. Bacher said he had that letter and that he had given it to Mr. Lumley or Mr. Jennings. Why, then, was Lumley not forthcoming? Why was not Jennings, the solicitor, called? He was wanted yesterday, but instead of calling him they called his clerk ... the evidence of Dr Bacher was wholly unworthy of credit, which was proved by the simple fact that he had never mentioned the letter in his affidavit in Chancery .... As to the statement of Bacher that the money was actually in his hands, that statement was not worth even the breath required to utter it. Why was Lumley not called to support that statement?"68

We can see illustrated here a phenomenon that affects all tribunals: in resolving disputed questions of fact they tend to put faith in whatever method of proof is available to them. Thus, where facts are proved by written depositions, the court tends to assume the reliability of written testimony, as Lord St Leonards did on this point, and as other judges have done in similar circumstances. ${ }^{69}$. We should be mindful too of the practicalities of the preparation of affidavits under pressure of time. Bacher said in re-examination, revealingly, and a little plaintively, "When I made the affidavit in Chancery I was the whole night with the solicitor. I deposed to what was pointed out by the solicitor" ${ }^{70}$ It is hardly surprising that affidavits prepared in these circumstances sometimes failed to stand up to subsequent scrutiny. To some degree it was inevitable that the Chancery court should trust the affidavits: a tribunal must have faith in its own factfinding method, and we should remember that oral evidence also has its deficiencies, and that cross-examination is not an infallible way of establishing the truth. ${ }^{71}$

When it came to the trial, Lumley's counsel pressed an alternative argument that, even if Bacher had not tendered the money on March 10, the time for payment had been impliedly extended to and beyond April 5 by a letter written, in French, by Albert Wagner to Lumley in March saying "if you send the bill of exchange, be good enough to address it either at this time to Berlin, or from (dès) the 2nd of April, to Hamburgh, to Engel \& Co,

${ }^{68}$ The Times, February 22, 1854, p. 11b; Moming Chronicle February 22, 1854, p. 11 b. ${ }^{69}$ Dr Lushington, in The Martha (1859) Swab. 489 at p. 490 (Admiralty Court).

The Times, February 21, 1854, p. 9f.

1832 xxiv; Waddams, Sexual Slander Ninetenth-Century England: Defanation in the Ecclesiastical Courts, 1815-1855 (2000), pp. 79-81.

(2001) 117 L.Q.R., JuLY (C) SweEt \& MAXWELl AND Contributors
Ferdinand Street, where we shall remain some time ..." ${ }^{72}$ Lord Campbell directed the jury that they could find that the time for payment had been impliedly extended, and it seems likely that this was the basis for the jury finding that the contract remained in force on April $5 .{ }^{73}$ It was a plausible inference from the letter that the Wagners were willing to receive payment some days later than April 5, though it is not a necessary corollary that they intended to waive any right they then had to terminate the contract.

Another observation may be made on these two disputed questions of fact, namely, whether Bacher had prior authority, and whether he had offered to pay the $£ 300$ on March 10 . On both questions Bacher's evidence was eventually shaken, but on neither point did this tum out to be crucial, because the legal issues were reformulated so as to make the disputed facts legally irrelevant. On the question of authorisation, as we have seen, it was found that, even though Bacher had no prior authority, yet the disputed clause was made part of the contract, because the apparent "contract" was recategorised as a counter-offer, to which Wagner was found to have impliedly assented at a subsequent time. Somewhat analogously, the fact that the advance money had not been paid on March 15-apparently an important breach of Lumley's obligation-also turned out not to be crucial, and curiously enough for three quite different and inconsistent reasons: in the Vice-Chancellor's court because it was found not to be a condition precedent, in the Lord Chancellor's court because it was found as a fact that Bacher had offered to pay by his letter of March 10, and (when Bacher's evidence on this point was later shaken) in the common law court because the time for payment might have been impliedly extended to and beyond April 5, and it was for the jury to say whether this had occurred. ${ }^{74}$ The interrelation between facts and law is complex, and facts that seem at first sight to be crucial can often be made irrelevant by redefinition of the legal issue, especially by use of the flexible technique of implications in contracts.

The substantial and most difficult issue in the Lord Chancellor's court was perceived to be whether the court, not having power (as was conceded) to order Wagner to sing for Lumley, might nevertheless issue an injunction to restrain her from singing for Gye. This was a debatable point on which the authorities were divided:

"Now this case has been very elaborately argued upon the authorities. I bow to the authorities and I mean to execute the authorities. I am

7219 L.T. 128. There was a dispute as to whether "dès" meant "not later than", or "after", and expett evidence was adduced both in the Chancery court and at the trial on this point. There is an oddity (though perhaps unavoidable) in English courts determining, on the evidence of experts in the French language, the

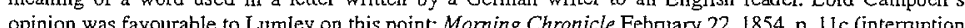
of Gye's counsel) and February 23 , p. 7 f (direction to juy).

${ }^{74}$ ibid.

(2001) 117 L.Q.R., July @ Sweet \& MaXwell AND Contributors 
assuming no power of my own; I am giving no authoritative decision of my own; but I mean to follow the current of authority; and as there is no doubt a difference of opinion between the learned judges who have preceded me, I mean calmly and patiently to consider in what the difference consists, and to arrive at the best conclusion I can, but meaning to follow the better authority as I find it." 75

It was argued for the defence that such an order would be an attempt to do indirectly what the court could not do directly. Lord St Leonards struggled with this point at considerable length, concluding that the court did have jurisdiction to issue the injunction, and distinguishing prior cases in which injunctions had been refused that would have enforced part only of a contract:

"I exercise the jurisdiction wholly within the power of the court; touch no subject over which I have not jurisdiction; I go to the whole extent of the jurisdiction; I leave nothing unaccomplished by my order which it is in the power of the court to accomplish; $I$ leave nothing to the future; I am of opinion that this is a proper case for interfering and in doing so I leave nothing unsatisfied: I leave nothing uncovered by the judgment which I shall pronounce. It is not, therefore, a case in which, by making an order on this particular covenant, I leave something not covered by it, because, as the one does cover the other, it is undeniable that if I restrain this young lady from singing at Covent-garden she cannot do so, and that the natural effect of that will be (although that is not the object which the Court has, because the Court cannot indirectly do a thing), the performance of the act which she is bound to do. Of this she has no right to complain. I deprive her of no right. I take away from her no remedy. She has no remedy at law The remedy is not a remedy by her, but a remedy by Mr. Lumley against her. Because I have granted an injunction restraining her from doing an act which she was bound not to do, will be no answer to an action by Mr. Lumley against her... My injunction will have this effect. It will prevent her from doing the other act; it will, in the event of an action being brought against her, prevent any such amount of vindictive damages being given as a jury might probably be inclined to give, if she had carried her talents and exercised them at the other and rival theatre. It appears to me, therefore, that in the exercise of this particular jurisdiction, I shall do nothing contrary to the settled rule of the Court, but that I shall do simply that which the Court has power to do-namely to carry into effect, as far as I am enabled, the whole power of the Court on one subject and that subject bearing-I say frequently bearing-for the purposes of justice, indirectly on the performance of that which I cannot enforce. But I do not continue the injunction on that ground, because I disclaim doing indirectly that which I cannot do directly, but I say it is a fortunate thing for justice

${ }^{75} 19$ L.T. 265.

(2001) 117 L.Q.R., JuLy @ SweEt \& MAXwell and Contributors if it does indirectly induce this lady to do the act which she is bound to execute." 76

This laboured language signifies, as laboured language usually does, a difficulty: it was admitted that contracts of personal services were not specifically enforceable, and Lord St Leonards felt the force of the argument that specific enforcement should not be decreed indirectly by an injunction. This would have been an unanswerable argument in the case of an ordinary employee. A crucial aspect of the case was that Johanna Wagner was not an ordinary employee.

It is reasonable to suppose that the Lord Chancellor remembered the earlier case of Jenny Lind, ${ }^{77}$ where, as we have seen, Lumley profited from Lind's breach of contract. ${ }^{78}$ In the later dispute, where Lumley was the aggrieved party, Lord St Leonards evidently considered that a law that permitted such a result was gravely defective: the real dispute was between the two opera houses, and a money remedy against Johanna Wagner personally would be wholly inadequate to protect Lumley's legitimate interest. Lord St Leonards said that "men are not suffered by the law of this country to depart from their contracts at their pleasure, and to leave the party with whom they have broken their contract to the mere chance of what a jury may give in point of damages", a probable reference to the jury award of $£ 2,500$ in Bunn $v$. Lind. He linked this point with a striking comment on public policy: "I have always thought that you may attribute a great deal of the right and fair dealing which exists between Englishmen to the exercise of that power [i.e. of specific performance] in this Court . This Court enforces where it can, a literal performance, and it is that literal performance which is here called a specific performance, which I believe has tended to that good faith which exists perhaps to so great a degree in this country, and certainly to a much greater degree than in many others." 79 Even when allowance is made for the prevailing mood of national selfcongratulation, this is very strong: it has not generally been thought that English law is to be distinguished from other systems by its greater readiness to decree specific performance of contracts, or that this littleknown feature of the law is crucial to the national character. There is probably an implicit reference here to Albert Wagner's comment in his February letter to Bacher that "England is only to be valued for the sake of

${ }^{76} \mathrm{ibid}$. The corresponding passage in De Gex, M'Naghten and Gordon's report, at pp. 619-620, is drastically abbreviated. The Law Times report bears the marks of being closer to a verbatim report. The report in The Times, May 27, 1852, p. $6 \mathrm{f}$ is intermediate in its degree of det

Lond St Eeonards' reference, infro, to the "mere chance of wh

${ }^{78}$ See supra, n.

(2001) 117 L.Q.R., Juty (C) SWeet \& MAXwell ANd CONTRIBUTORS 
her money" 80 - a comment widely and indignantly quoted in the English press. $^{81}$

Putting these points together, it is clear that Lord St Leonards formed a hostile view of Johanna Wagner's and her father's and Gye's actions and motives. He perceived the real dispute as being between the rival opera houses, and the existing state of the law (exemplified by Bunn v. Lind) as most inadequate to protect Lumley's interests: if Wagner sang for Gye, irreparable damage would have been done; an award of damages against Wagner by a common law court at some future date would almost certainly be too little and too late; even if a jury were prepared to award adequate damages (which he evidently thought very doubtful), Wagner might be unable to pay, or might very probably be beyond the jurisdiction of the English courts. In short, as one of Lumley's counsel had put it, "to suppose that Lumley could be properly compensated by damages through an action at law was farcical". ${ }^{82}$ An injunction against Wagner was therefore the only practicable way of protecting Lumley's legitimate interest against Gye. Gye had agreed to indemnify Wagner against all costs and damages, and he conducted, and was perceived to conduct the defence. The same solicitor and counsel represented both, and Gye was in constant consultation with them.$^{83}$ Gye was named as a defendant, and the injunction was issued against him personally, ${ }^{84}$ as well as against Wagner, although, as the common law then stood, Gye had committed no legal wrong.

Non-legal opinion supported the injunction for similar reasons. C. L. Gruneisen, a very influential contemporary music critic, after referring to the damage award in Bunn v. Lind and contrasting the effect of the injunction in the Wagner case, praised the injunction, in spite of his having a close association with Covent Garden: "these transactions of artistes entering into double engagements with rival impresarios were very disgraceful, and have been fortunately put an end to by the wholesome influence of a Chancery injunction". 85

Lumley $v$. Wagner and cases that have followed it have sometimes been criticised as imposing an undue restraint on personal liberty. ${ }^{86}$ This is an important consideration, and some of the later cases may be vulnerable to this criticism. But it should be noted that on the facts of the case itself the

${ }^{80} 19$ L.T. 128

See The Times, April 27, 1852, p. 8d (lefter to editor); May 3, 1852, p. 5f ("Spectator"); May 11, 1852 p. $5 \mathrm{~b}$ (leading article).

${ }^{83}$ Gye's diaries, April 23, 25, 26, 27; May 6, 7, 11, 22, 1852

${ }^{84}$ Entry book of decrees and orders, P.R.O. C33/1007, ff. 687, 850

${ }^{85}$ Gruneisen, The Opera and the Press (1869), p. 10. Gruneisen had been involved in the establishment of the Royal Italian Opera at Covent Garden, and was (in 1852) the music critic for the Morning Chronicle and for the Illustrated London News: Dictionary of National Biography, s.n. Gruneisen.

${ }^{80}$ See, for example, R. S. Stevens, "Involuntary Servitude by Injunction" (1921) 6 Cornell L.R. 235 J. D. Heydon, The Restraint of Trade Doctrine (1971); pp. 64-71; VanderVelde, "The Gendered Origins of

(2001) 117 L.Q.R., July @ SweEt \& MAXwell AND CONTRIBUtors effect of the injunction could scarcely be described as oppressive. Johanna Wagner was restrained from performing in England only (not her normal sphere of professional activity) for a period of three months only. Suggestions that she was faced with the choice of singing for Lumley or starvation $^{87}$ are quite wide of the mark. She had received $£ 1,000$ from Gye--almost as much as she expected from Lumley for full performance of her contract and an enormous sum in relation to "starvation". She remained in a strong position to refuse to sing for Lumley, and she did refuse, despite Lumley's efforts. ${ }^{88}$

The decision in Lumley $v$. Wagner might be said to amount, in practical effect, to a decision that Gye (on the facts stated in the affidavits) was to be treated as a wrongdoer. It remained for the common law court to confirm this as a matter of law, which was done in Lumley $v$. Gye. Lumley brought an action against Gye claiming damages of $£ 30,000{ }^{89}$ The declaration (statement of claim) stated that Gye, knowing of the contract with Lumley, had "wrongfully and maliciously enticed and procured" Johanna Wagner to break her contract. This was a novel claim in relation to professional services, and Gye demurred. This procedure (demurrer) enabled the Court of Queen's Bench to determine, before any evidence was heard, whether, assuming the facts alleged in the declaration to be proved, Lumley would be entitled to succeed.

It was vigorously argued on Gye's behalf that in order to succeed "the plaintiff must have a property in the thing taken away" and that "the breach of contract is a wrong between the plaintiff and Johanna Wagner alone, and against her he may maintain an action on the contract, but not of tort". ${ }^{90}$ It will be seen from this that the categorisation of the case was perceived to be crucial, and property concepts as well as contract and tort concepts were argued.

The court of Queen's Bench, by a majority of three to one, decided the issue on the demurrer in Lumley's favour. As in the Chancery courts, the majority emphasised the inadequacy of a contractual action against Wagner, and again it is likely that they had in mind the facts of Bunn v. Lind

\footnotetext{
${ }^{87}$ Gardner, "The Proprietary Effect of Contractual Obligations under Tulk v. Moxhay and De Mattos v Gibson" (1982) 98 L.Q.R. 279 at p. 281.

${ }^{88}$ Gye's diary, May 14, 1852; "Johanna told me Lumley's emissaries were after her father but they did not seem to think of singing at H.M.'s Thearren. Negotiations took place with a view to dividing he Wagner to decide for herself, and she decided not to sing in London at all in 1852: Gye's diaries, May 27 , 31: June 8, 10,11. At one point there was a fear that Lumley might cause the Wagners to be arrested on a writ of ne exeat regno. This would have been oppressive, and Gye wrote, "None of our legal men had a writ of ne exeat regno. This would have been oppressive, and Gye wrote, "None of our legal men had from England, but Johanna was too ill to travel that night, and the next day Gye's legal advisers decided

that the power to arrest did not exist after all: Gye's diaries, May 6 and 7, 1852
89 20 L.T. 103, The Times, February 10, 1854; Moming Post, February 23, 1854, p. 7c; Morming Chronicle, February 23,1854 ; p. 8a. Lumley gave the figure as $£ 20,000$ in his Reminiscences, p. 333. 9022 L.J.Q.B. 466 (Willes).
}

(2001) 117 L.Q.R., July (C Sweet \& Maxwell and Contrubutors 
(Erle J., one of the judges, had tried that case), ${ }^{91}$ and that they took account of the fact that Johanna Wagner was likely to be outside the jurisdiction of the English courts, and without the means of paying large damages. Crompton J. said, of the contractual action, that "the servant or contractor may be utterly unable to pay anything like the amount of the damages sustained entirely from the wrongful act of the defendant: and it would seem unjust, and contrary to the general principles of law, if such wrongdoer were not responsible for the damage caused by his wrongful and malicious acts".

Coleridge $\mathbf{J}$, in a very vigorous dissent, argued that a rule that anyone who advised another to break a contract was guilty of a tort was far too wide:

"None of this reasoning [about liability for encouraging torts] applies to the case of a breach of contract: if it does I should be glad to know how any treatise on the law of contract could be complete without a chapter on this head, or how it happens that we have no decisions upon it. Certainly no subject could be more fruitful or important; important contracts are more commonly broken with than without persuaders or procurers, and these often responsible persons when the principals may not be so." 92

Coleridge $J$. distinguished the old master and servant cases on the ground that they in effect recognised a kind of property right in services, and were not to be extended to independent contractors like Johanna Wagner.

Lumley $v$. Wagner is "a contract case", whereas Lumley v. Gye is "a tort case", and very rarely are the two discussed together. But when they are considered together it can be seen that the concepts of breach of contract and of wrongdoing equally affected both, and that considerations of unjust enrichment, property rights, and public policy were also in play in both cases. What was the relation among these concepts? I would suggest that the judicial conclusions were reached by considering all of these concepts simultaneously, and not by contemplating each of them separately, as though they lay apart from each other on a pre-existing map or scheme. ${ }^{93}$

Let us consider first the tort aspects. No previous case, as the majority in effect conceded, ${ }^{94}$ had imposed tortious liability in like circumstances, nor

\footnotetext{
${ }^{91}$ The Times, February 23, 1848, p. 7 d.

${ }_{92} 2$ El. \& Bl. 250

${ }^{93}$ G. Sarnuel, "Can Gaius Really be Compared to Darwin?" (2000) 49 I.C.L.Q. 297 warns against applying a zoological classification scheme to legal concepts.

${ }^{24}$ Crompton J. held that "the parties are in the relation of employer and employed, or master and servan within the meaning of this rule [emphasis added]. And I see no reason for narrowing such a rule, but should rather, if necessary, apply such a reasoning to a case "new in its instance but not in the reason and principle of it' " (citing Keeble v. Hickeringill, 11 East 573): $2 \mathrm{El}$ \& \& Bl. 754. In Barber v. Lesiter (1859) 7 C.B. (N.S.) 175, 185, and Lynch v. Knight (1861) 9 H.L.C. 577 at pp. 586-587, Lumley v. Gye was cited in argument for the proposition that the absence of precedent was not conclusive against creation of a new cause of action.
}

(2001) 117 L.Q.R., Juty @ Sweet \& Maxwell and Contributors was Lumley $v$. Gye afterwards followed for nearly 30 years. ${ }^{95}$ We may reasonably ask, therefore, what it was about the particular case that led the court to think that tortious liability was appropriate. The answer I suggest is that it was a cumulation of considerations. The court had the example of Bunn v. Lind before its eyes: that was a case where the law had shown itself most inadequate, permitting a handsome profit to be made from breach of contract, and encouraging a kind of cut-throat competition in the theatre business that was in no-one's interest. In the Wagner case the Court of Chancery had given an injunction, rightly, as the common law judges probably thought, for this had been the only way to prevent Gye from profiting from his own wrongdoing at the expense of Lumley's legitimate business interests. But if the injunction had been rightly granted, Gye's conduct must have been, legally speaking, wrongful; and this conclusion was to be welcomed: it was not in the public interest for the law to permit persons to profit from wrongdoing as Gye sought to do.

Can it be said that Lumley had a proprietary interest? Certainly no preexisting account of property law would have included such a case, and the Lumley cases do not appear in modem books of property law, but "property" is not a self-explanatory nor a clearly defined concept, and it may plausibly be maintained that the willingness of the one court to grant an injunction, and the willingness of the other to hold Gye liable in tort, can be described as a recognition of something like a proprietary interest in Wagner's services in London for the three-month period. ${ }^{96}$ 'The link between equitable remedies and proprietary interests is well-established, ${ }^{97}$ and modern commentators have extended it, suggesting that one mark of what we may reasonably call a proprietary interest is an interest that the law protects by injunction. ${ }^{98}$ In the Queen's Bench, Erle J. said that "he who maliciously procures a damage to another by violation of his right ought to be made to indemnify". ${ }^{99}$ The crucial phrase here, "by violation of his right" must (unless it is completely circular) be linked with some sort of proprietary concept. Anson, writing in 1879, also suggested that Lumley v. Gye might be regarded as creating a right in rem, and he doubted the correctness of the decision for just this reason:

"The case stands alone (it was decided in 1853) and no reported attempt has since been made to bring an action for a like case. But it

${ }^{95}$ Bowen v. Hall (1881) 6 Q.B.D. 333.
${ }^{96}$ Gardner, op. cit. supra, n. 87 , p. 322.

${ }^{97}$ See Tailby v. Official Receiver (1888) 13 App. Cas. 523, International News Services $\%$ Associated Press 248 US 215 (1918), where a news service was enjoined from copying news from a rival service, is often regarded as creating a proprietary interest. Similarly, where a contractual licence is enforced by injunction, the licensee is often said to have a proprietary interest: see Millennium Productions Ltd $v$. Winter Garden Theatre (London) Ltd [1948] A.C. 173.

${ }^{98}$ Calabresi and Melanned, "Property Rules, Liability Rules and Inalienability: One View of the Cathedral" (1972) 85 Harv.L.Rev. 1089; L. Kaplow and S. Shavell, "Property Rules Versus Liability Rules: An Economic Analysis" (1996) 109 Hary L Rev 715

(2001) 117 L.Q.R., JuLY $\odot$ SWEET \& Maxwell AND CONTRIBUtors 
is important to bear in mind that a considered judgment of the Court of Queen's Bench has laid it down that a contract confers rights in rem as well as in personam; that it not only binds together the parties by an obligation, but that it imposes upon all the world a duty to respect the contractual tie." 100

Unjust enrichment is not a phrase that occurs in either of the two cases, but the concept is present throughout. The whole gist and tenor of the judgments in both courts is that Gye was seeking to reap where he had not sown and that he ought not to profit at Lumley's expense. But this does not mean that the case could or should be classified as an "unjust enrichment" case. Restitution scholars have differed on the question of whether profits derived from wrongdoing form part of the law of unjust enrichment or of the law of wrongs. ${ }^{101}$ I would suggest that the two concepts (wrongdoing and unjust enrichment) though distinct, are also related to each other in a complex way. The question whether Gye is unjustly enriched and the question whether Gye is a wrongdoer cannot be independently resolved: it is the very fact that Gye's enrichment from the transaction is perceived as unjust that leads the court to the conclusion that his conduct is wrongful, just as the same considerations lead to the conclusions that Lumley had something like a proprietary interest and that it should be protected by injunction.

Public policy considerations played an important part in both cases. Lord St Leonards' comments linking specific performance with national good faith have been noted, and these were echoed by commentary in the contemporary press. ${ }^{102}$ In the Queen's Bench, Crompton J. said that "it would seem unjust, and contrary to the general principles of law" if Gye were not (on the facts assumed) to be liable. Erle and Wightman JJ. were also plainly influenced by very general considerations of justice and policy. ${ }^{103}$ Another aspect of public policy relates to freedom of action, particularly free competition. Lumley had a legitimate business interest in having his contractual arrangements with singers respected, at least where they were reasonable and for a short term. Any trade association of theatre managers would have had, as its first item of business in 1852, the restraint of the most extreme forms of cut-throat competition, and such a measure

${ }^{100}$ Anson, Principles of the Law of Contract (1879), p. 199

${ }^{10 t}$ Gains from wrongs are included in the concept of unjust enrichment in the Restatement of the Law of Restitution (American Law Instiute, 1937), and by Goff and Jones, Law of Restitution (1966); Birks, p. 34; Beatson, The Use and Abuse of Unjust Enrichnent (1991); Burrows, Understanding the Law of Obligations (1991), but excluded (or excluded from "autonomous" unjust enrichment) by Birks, "The Concept of a Civil Wrong", in D. G. Owen (ed.), Philosophical Foundations of Tort Law (1995), p. 37; L. Smith, "The Province of the Law of Restitution" (1992) 71 Can. Bar Rev. 672; Birks, "The Role of Fault in the Law of Unjust Enrichment", in The Search for Principle, Swadling and Jones (eds, 1999), 235 at p. 236; McInnes, "The Canadian Principle of Unjust Enrichment: Comparative Insights into the Law of Restitution". (1999) 37. Alla L.Rev. 1.

102 See supra, n. 81.
${ }^{103}$ See Erle J., supra and Wightman J. at p. 238 ("general principle").

(2001) 117 L.Q.R., JulY (C SWEet \& MAXWELl and CONTRIBUtors would (if challenged as a restraint of trade) probably have been upheld as reasonable. This point is connected with the recognition of a proprietary interest. The business of presenting operas in a musical marketplace where the audience was attracted primarily by individual star performers could not reasonably be carried on without some kind of assurance that contracts with the principal singers were firm, at least for limited periods. Works had to be translated, permissions obtained, costumes and scenery prepared, the cast assembled, rehearsals held, performances advertised, and tickets sold. Evidence at the trial showed that Lumley "had embarked considerable capital in the undertaking", and had made a public announcement that Wagner would be singing at his theatre. ${ }^{104}$ Moreover, the theatre's reputation and the value of its good will were at stake; it stood to lose large amounts, difficult to quantify, if Wagner failed to sing, and still more if she conferred a corresponding gain on the rival theatre.

The courts' conclusions in the two cases were not derived from strict logic, and no computer, even with all previous decisions in its database, could have predicted them. ${ }^{105}$ Taken separately, each strand in the reasoning is open to the accusation of circularity, but cumulatively, as often in legal reasoning, ${ }^{106}$ the various concepts tend to support each other, and form a persuasive argument for the result. All legal propositions, whether formulated in the court room, or in the lecture room, or in writing, are tested by an appeal to judgment, something that cannot be constrained by strict logic. Considerations of logic and internal coherence are not irrelevant in legal argument, but neither are they conclusive. It is always an answer to any legal proposition to show that it would lead to results that speaker and listener, or writer and reader, both judge to be unacceptable.

The point about interrelationship of concepts may be taken a step further. I would suggest that the tendency to make too sharp a separation of legal concepts from each other may lead, and in the case of Lumley v. Gye has led, to the formulation of legal rules far wider than necessary to explain the result in the particular cases, with consequent enlargement of liability in subsequent cases where the circumstances have differed in crucial respects. Let us consider first the proposition in Lumley $v$. Wagner that "English law enforces, where it can, a literal performance of the contract". ${ }^{107}$ This is certainly not an accurate statement of the law of specific performance, and,

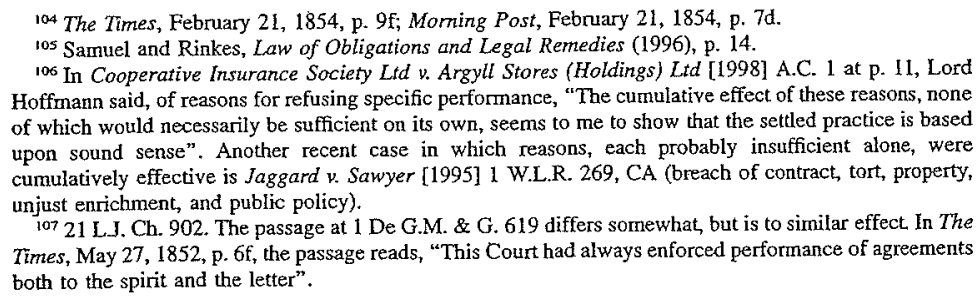
of which would necessarlly be sufent case in which reasons, each probably insufficient alone, were cumulatively effective is Jaggard \%. Sawyer [1995] \& W.L.R. 269, CA (breach of contract, tort, property, unjust enrichment, and public policy).

${ }_{107} 21 \mathrm{LJ}$. Ch. 902. The passage at 1 De G.M. \& G. 619 differs somewhat, but is to similar effect In The Times, May 27, 1852, p. 6f, the passage reads, "This Court had always enforced performance of agreement both to the spirit and the letter

(2001) 117 L.Q.R., July (C) SWeEt \& MAXWell ANd Contributors 
had it been applied, it would have led, as I have argued elsewhere, to very much inconvenience and injustice. ${ }^{108}$ If this passage were relied on in argument in a modern case on specific performance, the court would probably say that Lord St Leonards' words had to be read in their context, where the circumstances of the particular case showed that there were good reasons for granting the injunction. ${ }^{109}$ There is good reason for caution in extending the case, because against the plaintiff's interest must be set the defendant's interest in freedom to break her contract on payment of money compensation for the loss (if any) caused by the breach. ${ }^{110}$ The defendant's right is not absolute, but it is an important aspect of personal freedom, and should only be overridden for sufficient reason. The considerations that will tend to justify an injunction will include the following (all present in Lumley $v$. Wagner): the restraint on the defendant's freedom of action is comparatively slight; the plaintiff has a quasi-proprietary interest; a money remedy would be ineffective; and the defendant is likely (unless the injunction is issued) to confer an unjust benefit on a competitor of the plaintiff. It is these considerations, I suggest, that lie behind the rules, adopted in many common law jurisdictions, to the effect that an injunction will not be issued unless the defendant's services are unique, and that the plaintiff must have an interest in restraining the defendant's conduct that is independent of the interest in inducing performance of the positive side of the contract. "I In the recent case of Att.-Gen. v. Blake, Lord Nicholls of Birkenhead suggested a similar criterion for determining when there should be an accounting of profits made in breach of contract. An accounting would be appropriate, he suggested, where the plaintiff had a legitimate interest in preventing the defendant's profit-making activity. ${ }^{112}$

Thus, Lumley $v$. Wagner has been, in many common law jurisdictions, rather narrowly confined, but the same cannot be said of Lumley $v$. Gye, which has been extended to circumstances very far removed from those of the original case. Why, one may ask, should this be? ${ }^{113}$ The wide proposition that deliberate inducement of a breach of any contract amounts

${ }^{108}$ See Waddams, "The Choice of Remedy for Breach of Contract" in Beatson and Friedmann (eds), Good Faith and Fault in Contract Law (1995); Waddams, "Breach of Controct and Friedmann (eds), ${ }^{109}$ This is partly what is meant by the saying that equitable remedies are "discretionary" A recent example of refisal of a decree of specific performance is Cooperative Insurance Society Ltd $v$. Argytl Stores (Holdings) Lid, supra, n. 106.

"111 See Waddams, op. cit. supra

D.I. See Whitwood Chemical Co. v. Hardman [1891] 2 Ch. 416, CA; Macdonald v. Casein Ltd (1917) 35 D.L.R. 443; Detroit Football Co. v. Dublinski (1956) 4 D.L.R. (2d) 688, revs'd on other grounds 7 D.L.R. (2d) 9; Corbin on Contracts (1964) s.1206; Spry, Equitable Remedies (5th ed., 1997), pp. 603-604; R. J. Sharpe, Injunctions and Specific Performaince, (3rd ed., 2000), para. 9.300; Fannsworth, Contracts (1982), p. $156-158$.

${ }_{132}$ Att.-Gen. v. Blake [2001] A.C. 275 at p. 285.

113 Tony Weir has pointed out the inconsistency of favouring "efficient breach", while treating as tortious
an inducement to break a contract: Economic Torts (1997), p. 4 .

(2001) 117 L.Q.R., JULY (C) SWEet \& MAXWELL AND CONTRIBUTORS to a tort has led to much difficulty, and (I would suggest) ought not to be accepted in so wide a form. The case of a father advising his daughter to break an engagement of marriage is one where there is a strong public interest in freedom of action on the part of both. No injunction would be issued against the daughter, nor is an action in tort appropriate against the father. Again, generally speaking, an ordinary employee is free in modern times to change employment, even without giving proper notice to a former employer, subject to the obligation to pay damages. It would be an undue restriction on that freedom either to restrain the employee by injunction, or to hold the second employer, even with knowledge of the inadequate notice, liable in tort. Lumley $v$. Gye can and should be distinguished from such a case just because it was not a case of an ordinary employee. Johanna Wagner was a "hot property", and it was precisely for this reason that the injunction was granted. The case therefore is a very special one, and hardly need stand for the general proposition that inducement of all breaches of contract is always tortious. It could equally be explained by postulating a rule that inducing breach of contract is wrongful where it infringes something in the nature of a proprietary interest, where it causes an unjust enrichment, and where the public policy favouring freedom of action is outweighed by strong countervailing considerations.

In practice the courts have not always attached all the usual consequences of torts to inducing breach of contract, and various restrictions have been placed on its scope by the requirements of intention, by the evolution of special defences of privilege and justification, ${ }^{14}$ and, in the field of industrial relations, by specific legislation, ${ }^{15}$ but because so wide a rule has been deduced from Lumley v. Gye, these restrictions appear to be anomalous and unprincipled. In a modern case, where a boxer endeavoured (in breach of contract) to engage a new manager, an injunction was sought by the old manager to restrain the new manager from inducing breach of the prior contract. The injunction was refused by the English Court of Appeal on the ground that it would be an undue restraint on the boxer's freedom to compel him to retain a manager in whom he had lost confidence. ${ }^{116}$ The refusal of the injunction in effect protects the boxer's freedom to break his contract with the first manager. If inducing breach of contract were treated as in all cases tortious, the managing officers and employees of a corporation who caused it to break a contract would be personally liable in tort. The undoubted need to create an exception here from ordinary principles of tort liability strongly suggests that not every

114 See Fleming, The Law of Torts, (9th ed, 1998), pp. 762-765.

11.5 Trade Disputes Act 1906, 5.3. See Glasbeek, "Lumley v. Gye. The Aftermath: an Inducement to Judicial Reform" (1975) 1 Monash U.L.R. 187

W. Warren v. Mendy [1989] 1 W.L.R. 853, CA. See also Page One Records Ltd. v. Britton [1968] 1

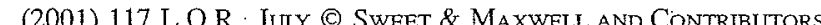


inducement of breach of contract can be treated as wrongful. ${ }^{117}$ Consider in this context a case where the cost of performance greatly. exceeds the benefit of it. ${ }^{118}$ Assuming, for present purposes, that the proper measure of damages for breach of contract is the economic value of performance to the plaintiff, it would be highly anomalous to allow this result to be circumvented by permitting the plaintiff to sue the managing officers of the corporation personally in tort and to recover damages measured in effect by the cost of performance, or exemplary damages.

I would suggest, therefore, that it is not desirable to treat inducement of every breach of contract as a wrong. It is not possible to specify precisely the kinds of contract in respect of which inducement of breach should be tortious, because attention must be given to several concepts simultaneously. In general terms it may be suggested that inducing breach of contract should be wrongful when, but only when, it enables the defendant to take something that belongs to the plaintiff. ${ }^{19}$ This concept cannot be precise, but is likely to include those classes of case where the plaintiff has a special interest in performance such as would not be adequately protected by an award of compensatory damages, that is, as the Lumley cases themselves demonstrate, the very kind of case in which the court is likely to favour specific relief, where also the court is likely to categorise the plaintiff's interest as proprietary, ${ }^{120}$ and to order profits derived from the breach to be restored to the plaintiff (either by the contract-breaker or by the third party, or both). ${ }^{121}$ The concepts tend to support each other in a way that is circular, but not empty of content, nor lacking in persuasive power. Of course, this conclusion is untidy, but it may be said in response that interdependent legal arguments of this kind are very frequent, and that conceptual tidiness is not the highest object of the law.

We must now turn to the ultimate disposition of the litigation in Lumley v. Gye. The overruling of the demurrer was not, as has often been supposed, the end of the case. Relying on a provision in the then recent Common Law Procedure Act of 1852, Gye had obtained the court's permission to demur and plead, i.e. to argue the demurrer while reserving his right to dispute the

\footnotetext{
"17 Said v. Butt [1920] 3 K.B. 497; ADGA Systems Int. Ltd, v. Velcom Ltd (1999) 168 D.L.R. (4th) 351, Ont CA.

${ }^{113} \mathrm{As}$, for example, a contract to restore a building that is about to be demolished, or to run a business that is expensive to carry on but of no benefit to the promisee, or to restore a mining site, where the cost of restoration greatly exceeds the enhancement in the value of the land.

interest, e McChesney, "Tortious Interference with Contract versus 'Effficient" it protects a property Empirical Evidence", (1999) 28 J.L.S. 131. As with the question of profits derived from breach this line of argument does not support treating the breach of every contract as tortious, because not every contractual interest is for all purposes proprietary in nature.

${ }^{120}$ The case is comparable with the marketing of film and sports celebrities in later periods. See Wamer Bros Pictures Inc v. Nelson [1937] 1 K.B. 209; Flood v. Kuhn, 407 U.S. 258 (1972). 121 See Att-Gen. v. Blake, supra, n. 112; Waddams, "Breach of Contract and the Concept of
Wrongdoing" (2000) 12 Sup. Ct. L.R. 1.
}

(2001) 117 L.Q.R., JULY @ SWeET \& MAXWELl AND CONTRIButors facts later something that the old procedure would not have allowed. ${ }^{122}$ This new procedure rested on the assumption, refiecting the "scientific" spirit of the time, that the law could be satisfactorily declared in isolation from particular facts, an assumption that the ultimate result in Lumley $v$. Gye calls into question. Undoubtedly the drafter of the plaintiff's declaration thought that it stated facts sufficient to include Gye's conduct: "maliciously" would include "knowingly", and who knew better than Gye of Wagner's arrangement with Lumley? What the drafter failed to foresee, and what the Queen's Bench judges also probably failed to foresee, was that Gye would be able convincingly to assert that he honestly (though mistakenly and perhaps unreasonably) believed that Wagner was legally entitled to terminate her contract with Lumley.

The case was tried before Lord Campbell and a special jury, which answered specific questions. By another recent change in the law the parties were competent witnesses ${ }^{123}$ : Gye gave evidence, but Lumley did not, an omission of which much was made by Gye's counsel at the trial. ${ }^{124}$ Wagner herself was not available as a witness, though an unsuccessful attempt had been made to take her evidence by commission. ${ }^{125}$ As we have seen, Bacher's evidence was severely attacked by Gye's counsel, who suggested that he had sworn falsely in stating that Lumley had paid him the specific sum of $£ 300$ on account of the advance payment, and that he had offered it to Wagner. Bacher was also alleged to have a personal interest in the outcome of the action because his brother-in-law, Louis Brandus, a prominent Paris music publisher, had lent $£ 8,000$ to Lumley, and expected to be paid out of the proceeds of the action. ${ }^{26}$ The language of advocacy at this time tended to be forceful, and The Times report gives the flavour:

"That witness [Bacher] had called himself a doctor of civil law, when it appeared that he was a mere copying clerk in an advocate's office who had been employed by Mr. Lumley as his hack to do his dirty

22 A question arising out of the new provisions was litigated: 22 L.J. Ex. 9, 1 W.R. 39, 20 L.T. 71, 103 Tye wis required to make an affidavit that he believed he had a meritorious defence.

123
14 4 \& 15 Vic. c. 99

${ }^{124}$ Lumley's counsel said the reason for Lumley's absence from the witness box was that he did not wish to reveal his weak financial position, but this was not convincing as Her Majesty's Theatre had closed by the time of the trial. More probably his advisers feared that he would have diffculty in supporting the stric accuracy of some of the Chancery affidavits, in particular on the question of whether Lumley had paid Bacher a specific sum of money earnarked for transmission to Wagner. On this, Lumley had said in $\mathrm{his}$ affidavit that "Joseph Bacher had in his hands monies of and belonging to this deponent to the amount of four hundred pounds" (P.R.O. C3 L/861). Simular words appear inning account with Mr. Lumley. They [the

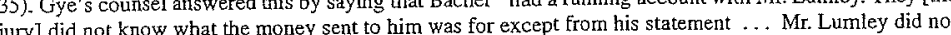
jury] did not ke in the box and comoborate the statement of Dr. Bacher because he knew what a crossdare to appear in the box vald co undergo": Morning Post, February 22, 1854, p. 6f.

${ }_{125}$ The court gave leave for a new commission to be issued, on payment by Gye of Lumley's costs of the abortive first commission: 3 El. \& Bl. 114, 22 L.T. 220 , 18 Jur. 466, The Times, February 23, 1854, p. $12 \mathrm{~b}$, but Gye did not pursue the matter because his counsel were afraid that if it was favourable to Gyc, Lumley would object successfully to its admissibility: Gye's Diary, January 17,1854 .

126 The Times February 21, 1854, p. 9f (cross-examination).

(2001) 117 L.Q.R., July @ SweEt \& MaXwell and Contributors 
work. He belonged to the firm of Lumley, Bacher, and Brandus, who hoped to be enriched by the plunder which they expected to get from the defendant in this action." 127

As mentioned earlier, the judge directed the jury that although failure to make the advance payment in time would have been fatal to Lumley's case, there was evidence from which they might conclude that the time for payment had been impliedly extended. ${ }^{28}$ The jury found this question in Lumley's favour, probably on the ground that the time had been extended. But Lumley lost the case, because on the crucial question of Gye's state of mind, the judge directed the jury that "if the defendant bona fide believed that the agreement with the plaintiff had ceased to be binding upon Miss Wagner the scienter was not proved, and the defendant would be entitled to the verdict", and on this point, the jury found for the defendant. ${ }^{129} \mathrm{~A}$ motion for a new trial was dismissed by the full Queen's Bench, Lord Campbell pointing out that the court had indicated in overruling the demurrer in the previous year that bad faith was an essential part of the tort. On this point Gye had given evidence that he honestly thought, on April 5, that Wagner was free from her obligation to Lumley. Lord Campbell commented, in supporting the dismissal of the motion for a new trial, that "the jury had believed Mr. Gye and he [Lord Campbell] was not prepared to say they were wrong". ${ }^{130}$ In a leading article the next day, The Times remarked that "there are some things of which we never expected to see the end, and among them was the litigation of LUMLEY v. GYE", concluding on a note of regret for the closing of Her Majesty's Theatre, which it considered superior to Covent Garden. ${ }^{131}$

The fact that Lumley eventually lost his case has been largely overlooked, and often misstated. There is some excuse for the error: the verdict is not very conspicuously reported in the law reports ${ }^{132}$; it was misleadingly described by Lumley in his memoirs, ${ }^{133}$ and the result was misstated in both relevant articles in the Dictionary of National Biography, ${ }^{134}$ and elsewhere. ${ }^{135}$ The result, however, is important to a full understanding of the case. The requirement that the plaintiff prove actual dishonesty on the defendant's part made the action substantially less attractive to plaintiffs than it might at first have appeared. Lumley's failure goes a considerable way to explain why no similar case was litigated for nearly 30 years: a defendant, in order to escape liability, had only to say that he honestly

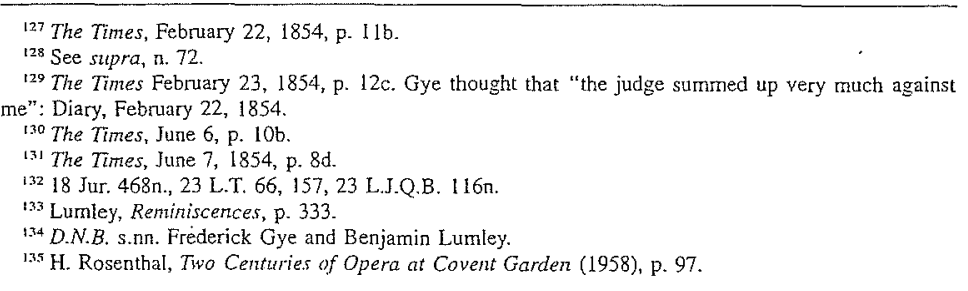

(2001) 117 L.Q.R., JuLY $\odot$ SWEET \& MAXWELL AND CONTRIBUTORS believed that the contract-breaker had some excuse, for which purpose a mistake, even an unreasonable mistake, on a point of law would suffice. It was suggested above that Lumley $v$. Gye might establish too wide a liability, if applied in circumstances where the features of the original case were absent. But it may also be suggested that the law on the defendant's state of mind may be too favourable to the defendant in a case where those features are present. Gye deliberately went behind Lumley's back-in a literal sense at Dover on April 2-to outbid him: he knew perfectly well that Lumley was asserting a right to Wagner's services; he knew that Lumley would certainly find the $£ 300$ immediately if he supposed it was crucial, and Gye refused Wagner's request to wait a few more days to give Lumley a further opportunity to do this ${ }^{136}$; on his own evidence Gye was shown the contractual clause requiring payment on March 15, but did not look at the rest of the contract or make further enquiry; Gye expected to be asked for an indemnity, and willingly gave it, anticipating that Lumley would litigate. ${ }^{137}$ Where the plaintiff has a legitimate interest that the court will protect by injunction and the defendant interferes with it for his own profit, knowing (as Gye knew) that the contract may very likely be enforceable, the defendant may be said to be reckless as to the plaintiff's interests, and imposition of liability would not appear to be unduly burdensome; it has often been held that recklessness is a sufficient mental element to support the imposition of liability for intentional torts. ${ }^{138}$ The general tone of the Queen's Bench judgments strongly suggests that all the judges expected that the court's decision would lead to Gye's being held liable. Had the facts been determined first, it seems very probable that the legal principle would have been formulated in such a way as to include "recklessness" or "turning a blind eye". ${ }^{139}$ Earlier it was suggested that a, consideration of the proprietary and unjust enrichment dimensions of the case might tend to favour restriction of the subsequent application of the Lumley cases. Here, that consideration tends to favour enlargement of their application, because there may be an unreasonable interference with proprietary interests, and an unjust enrichment, without any conscious wrongdoing. Thus, failure to perceive all the dimensions of the case may lead to the wrong results in both directions, and may have led to the wrong result in Lumley v. Gye itself.

${ }^{136}$ On the argument for a new trial Lord Campbell specifically asked counsel for an explanation of this, showing that he thought it was a weak point in Gye's case. The answer given was that Gye had already lost two days looking for the Wagners in Berlin and could not stay longer away from London: The Times, June 2, 1854 , p. 9f.

The Times, February 22, 1854, 11b. See supra in 52

A recent example is Three Rivers D.C. v. Governor and Company of the Bank of England (No. 3) 139 These expresich

1066] W. expressions have been used in modern cases, e.g. Emerald Construction Co. v. Lowthian, 
Pollock denied that the law was "reducible to patterns on a blackboard", ${ }^{140}$ but he did not advocate the destruction of blackboards. Equally it is impossible for the law to dispense altogether with such imagery as mapping and classification. Indeed, the imagery serves a useful purpose in reminding us that fundamental concepts in private law are distinct from each other and from other concepts. But these metaphors have a demerit: they tend to insulate the concepts from each other. The examination of the Lumley cases shows that fundamental concepts, including public policy, property, contract, wrongdoing, and unjust enrichment, though distinct, and each of fundamental importance, may often operate together and influence each other. A particular dispute cannot be readily allocated to one "area" or "branch" of the law to the exclusion of others, partly for the reason just mentioned, and partly because of the complexity of the interrelation of facts to law, also well illustrated in these cases. Too rigid a separation of legal concepts from each other and of facts from law tends to oversimplify, and oversimplification has serious consequences: it leads to the formulation of legal principles and rules that fail fully to explain past cases and that fail also to supply a satisfactory guide for the future.

S. M. WADDAMS.*

${ }^{140}$ Pollock to Holmes, January 24, 1921: Holmes-Pollock Letters, (1941), ii, 63.

* Faculty of Law, University of Toronto. I am very grateful for the generous help of Brian Simpson, and Francesca Franchi, Archiyist of the Royal Opera House, for the helpful connents of Jim Phillips, and for the assistance of Adam Taylor, Stephanie Chong, and Craig Lockwood.

(2001) 117 L.Q.R., July (C) SWeEt \& Maxwell AND Contributors 